\title{
Transformasi Komunikasi Politik Melalui Media Sosial Instagram (Studi terhadap Akun @karyaadalahdoa)
}

\author{
Terremi Michelle Chano, Sinta Paramita \\ michelle11cen@gmail.com,sintap@fikom.untar.ac.id \\ Fakultas Ilmu Komunikasi Universitas Tarumanagara
}

\begin{abstract}
The purpose of this study is to compare between recent political communication and how it used to be. This study was conducted specifically on the social media account @karyaadalahdoa. The transformation of political communication can be seen from the result of growth in ICT, namely the social media. @ karyaadalahdoa uses social media as a medium to spread their political messages in a creative and positive way. This study uses the Political Communication Theory, which according to Dahlan (as cited in Cangara, 2011) is a discipline that studies the communication behavior and activities that have political traits, have a political consequence, or have impact on political behavior. Basically, political communication not only involves an individual's interest, but also the public interest. This study uses qualitative method that includes deep interview with six informants. The study shows that the political communication in the late years was more relaxed and slow, while the current political communication is more straightforward and the spread of its information is faster due to the advancement of technology.
\end{abstract}

Keywords: Transformation of Political Communication, Political Communication, Social Media

\begin{abstract}
Abstrak
Komunikasi politik telah melakukan transformasi. Namun, yang perlu ditindaklanjuuti lebih yakni bagaimana transformasi komunikasi politik yang dulu dan sekarang dengan menggunakan media sosial. Penelitian ini dilakukan pada akun @karyaadalahdoa. Transformasi komunikasi politiknya bisa dilihat dari perkembangan teknologi dan informasi sekarang ini yang namanya media sosial. Akun@karyaadalahdoa ini menggunakan media sosial sebagai sarana penyampaian pesan politiknya yang dikemas secara kreatif dan positif. Menggunakan teori komunikasi politik menurut Dahlan ialah suatu bidang atau disiplin yang menelaah perilaku dan kegiatan komunikasi yang bersifat politik, mempunyai akibat politik, atau berpengaruh terhadap perilaku politik. Pada dasarnya komunikasi politik tidak hanya melibatkan kepentingan perorangan, melainkan kepentingan orang banyak. Penelitian ini menggunakan pendekatan kualitatif dengan teknik wawancara mendalam pada enam orang informan. Hasil penelitian dari akun @karyaadalahdoa menunjukkan bahwa transformasi komunikasi politik dulu lebih damai dan penyebaran informasinya sedikit lambat, sedangkan yang sekarang ini lebih terang-terangan dan penyebaran informasinya cepat dikarenakan kemajuan teknologi.
\end{abstract}

Kata kunci: Transformasi Komunikasi Politik, Komunikasi Politik, Media Sosial 


\section{Pendahuluan}

Kepala Badan Kependudukan dan Keluarga Berencana Nasional (BKKBN) Surya Chandra Surapaty menyebutkan pada 2016, penduduk remaja berusia 10-24 tahun berjumlah 66,3 juta jiwa dari total penduduk sebesar 258,7 juta sehingga satu di antara empat penduduk adalah remaja. Mungkin hingga tahun ini pun akan terus meningkat jumlah penduduk remaja, karena jumlah kelahiran pada tahun 2018 mencapai 4,81 juta jiwa. Dengan jumlah generasi milenial yang cukup besar ini bisa menjadi potensi yang memerlukan pengelolaan secara terencana agar dapat bermanfaat untuk bangsa indonesia kedepannya.

Masa remaja adalah masa peralihan dari masa anak-anak menuju masa dewasa. Pada masa ini remaja mengalami beberapa perubahan yang terjadi baik secara fisik, psikologis, maupun sosial. Menurut World Health Organization (WHO) dalam Panduan Pengelolaan Pusat Informasi dan Konseling Kesehatan Reproduksi Remaja (2006:6) remaja adalah yang berusia 12-24 tahun dan belum menikah. Menurut Departemen Kesehatan Republik Indonesia dalam Wirdhana (2011:77) remaja adalah yang berusia 10-19 tahun. Menginjak jenjang usia remaja mulai berpikiran untuk memiliki kebebasan mereka sendiri dan haknya untuk mengemukakan pendapat mereka. Remaja sudah termasuk ke dalam usia yang produktif, mereka bisa menyampaikan pendapat mereka terhadap apapun termasuk berkomunikasi yang berisikan pesan politik berbeda dengan zaman dulu remaja dianggap tidak bisa apaapa. Alasan remaja disangkutpautkan dengan politik ini karena peluang pemilih paling banyak adalah remaja.

Dalam keberlangsungan hidup, manusia membutuhkan komunikasi. Komunikasi sudah dianggap bagian dari kehidupan oleh orang-orang. Sebagian orang menganggap komunikasi itu mudah tetapi komunikasi tidak semudah yang terlihat. Banyak permasalahan yang bisa timbul hanya karena sebuah komunikasi yang salah pengertian terhadap satu sama lain. Komunikasi banyak jenisnya salah satunya adalah komunikasi politik ini. "Komunikasi politik merupakan komunikasi yang mengacu pada kegiatan politik" (Nimmo, 2007: 8). Semua kegiatan yang berbau politik termasuk ke dalam komunikasi politik. Komunikasi politik digunakan hampir dalam setiap komunikasi di masyarakat, baik itu interaksi lisan maupun tertulis.

Tahun 2018 dan tahun 2019 ini dianggap sebagai tahun politik. Tetapi tahun 2019 ini politik semakin panas, menurut Wasisto Raharjo Jati, peneliti politik dari Lembaga Ilmu Pengetahuan Indonesia. Dari kedua pasangan calon presiden dan wakil presiden sama-sama memiliki kandidat pendukung yang kuat. Penyebab politik memanas di tahun ini karena penyebaran kampanye hitam dan penyebaran isu yang mengatasnamakan suku, agama, bahkan ras. Maka dari itu, diperlukan pesan-pesan politik yang sifatnya ringan agar tidak memicu kesalahpahaman. Contoh pesan-pesan tersebut disampaikan melalui media sosial oleh relawan calon presiden nomor urut 1 .

Pada interaksi tulis, media yang paling sering digunakan dalam berkomunikasi adalah media sosial. Pada media sosial, pengguna dapat bertukar informasi, saling berkolaborasi, dan menjalin hubungan pertemanan dalam wujud tulisan, foto, atau video (Puntoadi, 2011).

Salah satu media yang paling banyak digunakan baik dari usia muda hingga dewasa adalah media sosial Instagram. Di media sosial Instagram ini banyak orang yang menggunakannya sebagai sarana menyampaikan pendapat mereka tentang politik. Salah satunya adalah akun @karyaadalahdoa ini berkampanye dengan sebuah 
karya yang kreatif. Komunikasi Politik ada kalanya bisa menyinggung hal-hal yang sensitif dan menyebabkan salah pengertian satu sama lain. Maka dari itu, menurut penulis terbentuknya akun@karyaadalahdoa ini suatu ide yang sangat dibutuhkan karena penyampaian pesan-pesan politiknya dilakukan secara kreatif dan tidak menimbulkan salah pengertian karena dari tutur bahasa yang digunakan sangat ringan dan mudah dipahami oleh berbagai kalangan.

\section{Metode Penelitian}

Penelitian kualitatif menurut Flick (dalam Gunawan 2014; 81), specific relevance to the study of social relations, owing to the fact of the pluralization of life worlds. Penelitian kualitatif adalah ketertarikan spesifik pada studi hubungan sosial yang berhubungan dengan fakta dari pluralisasi dunia kehidupan. Metode ini diterapkan guna melihat dan memahami subjek dan objek penelitian yang meliputi orang, lembaga berdasarkan fakta yang tampil secara adanya. Melalui pendekatan ini akan terungkap gambaran mengenai aktualitas, realitas sosial, dan persepsi sasaran penelitian.

Penelitian kualitatif ini berusaha menggali dan memahami pemaknaan akan kebenaran yang berbeda-beda oleh orang yang berbeda. Penelitian kualitatif cenderung lebih fleksibel dalam artian langkah selanjutnya ditentukan oleh temuan selama proses penelitian. Jadi bisa saja hasil akhirnya berbeda dengan apa yang dipikirkan oleh penulis pada awal pembuatan laporan.

Pendekatan penelitian kualitatif yang digunakan dalam penelitian ini dimaksudkan untuk memperoleh informasi mengenai transformasi komunikasi politik yang ada dalam media sosial Instagram akun @ karyaadalahdoa. Penelitian ini juga digunakan untuk mengetahui alasan di balik penggunaan media sosial Instagram untuk penyampaian komunikasi politik tetapi menggunakan sebuah karya. Dengan mendapatkan informasi ini maka dapat diketahui tranformasi komunikasi politik ini melalui media sosial instagram akun @ karyaadalahdoa.

Metode penelitian yang digunakan peneliti adalah penelitian etnografis virtual. Metode etnografi disini merupakan salah satu upaya mendalami suatu objek secara lengkap dan mendalam, sistematik dan sesuai sebagaimana hakikat objek tersebut. Sadar ataupun tidak, internet sudah menjadi bagian yang tidak terpisahkan dari realitas kehidupan kita sehari-hari. Akses internet yang semakin mudah dan murah memberikan kontribusi tak terhingga bagi realitas virtual dari entitas atau pengguna (user) di ranah virtual. Seolah-olah, bisa dikatakan, entitas menjadi terikat dengan dunia virtual dan dunia offline-online tidak hanya terhubung secara paralel, tetapi melebur dan menyatu (lihat Boellstorff, Nardi, Pearce, \& Taylor, 2012: 2). (dalam Nasrullah 2017: 1)

\section{Hasil Temuan dan Diskusi}

\section{Komunikasi Politik}

Menurut Dahlan dikutip dari Cangara (2011:29) ialah suatu bidang atau disiplin yang menelaah perilaku dan kegiatan komunikasi yang bersifat politik, mempunyai akibat politik, atau berpengaruh terhadap perilaku politik. Pada dasarnya komunikasi politik tidak hanya melibatkan kepentingan perorangan, melainkan kepentingan orang banyak. Karya adalah Doa sebagai penyampai pesan komunikasi politik yang dikemas secara damai, kreatif dan positif. Saat debat presiden akun 
@ karyaadalahdoa selalu meringkas pesan-pesan politik apa yang ingin disampaikan oleh Pak Jokowi-Amin yang memudahkan pengikutnya memahami pesan politiknya.

\section{Transformasi Komunikasi Politik}

Terdapat tiga dimensi penting ketika melakukan kajian tentang ruang-ruang komunikasi dalam konteks demokrasi, yaitu: dimensi struktural, representasional, dan interaksional (Dahlgren, 2005). Ketiga dimensi tersebut sebenarnya saling berkaitan, tetapi hanya dimensi struktural yang akan dibahas disini. Dimensi struktural mencakup sisi organisasi (media) seperti kepemilikan, kontrol, regulasi, serta aspek pengaturan yang menguatkan atau sebaliknya mengekang kebebasan berkomunikasi.

Transformasi yang digerakkan oleh media baru pada komunikasi politik terletak pada perubahan struktur komunikasi politik itu sendiri. Akibat yang paling signifikan dari perubahan struktur tersebut adalah posisi dan pengaruh aktor-aktor politik yang lebih setara baik dalam partisipasi maupun bobot diskursif yang dihadirkannya. Struktur komunikasi politik merupakan salah satu sisi yang berubah secara signifikan berkat media baru ini.

Akun@karyaadalahdoa ini menggunakan media sebagai platform komunikasi politiknya. Akun@karyaadalahdoa ini membuktikan jika penyampaian pesan politik sekarang ini harus mengikuti trend. Trend yang dimaksud adalah menggunakan media sebagai penyampaian pesan politiknya yang dikemas lebih menarik dibandingkan koran dengan penuh tulisan dan tutur bahasa yang kaku. Transformasi komunikasi politik dulu dengan sekarang bisa dibilang cukup signifikan dilihat dari penyebaran informasinya. Dulu penyebaran politiknya lebih terkesan lambat sampai ke masyarakat karena kurangnya teknologi, tetapi sekarang dengan berkembangnya teknologi semua lapisan masyarakat bisa mendapatkan pesan politiknya sangat cepat sepersekian detik saja.

\section{Media Sosial}

Menurut Van Dijk (Nasrullah, 2017; 11), menyatakan bahwa media sosial adalah platform media yang memfokuskan pada eksistensi pengguna yang memfasilitasi mereka dalam beraktifitas maupun berkolaborasi. Karena itu media sosial dapat dilihat sebagai medium (fasilitator) online yang menguatkan hubungan antar pengguna sekaligus sebuah ikatan sosial.

Media baru atau media online didefinisikan sebagai produk dari komunikasi yang termediasi teknologi yang terdapat bersama dengan komputer digital (Creeber dan Martin, 2009). Definisi lain dari media online adalah media yang di dalamnya terdiri dari gabungan berbagai elemen. Itu artinya terdapat konvergensi media di dalamnya, dimana beberpa media dijadikan satu (Lievrouw, 2011). New Media merupakan media yang menggunakan internet, media online berbasis teknologi, berkarakter fleksibel, berpotensi interaktif dan dapat berfungsi secara privat maupun secara publik (Mondry, 2008:13).

Akun@karyaadalahdoa ini menggunakan platform media sosial yang namanya media online untuk memberikan informasi melalui sebuah karya di media sosial seperti Instagram, Facebook, Twitter, maupun website mereka. Situs ataupun media sosial@karyaadalahdoa hadir untuk menjadi sarana kolaborasi karya kreatif bagi kita semua, saatnya kita berkarya bersama lagi, berupaya dan berdoa bersama untuk mewujudkan harapan dan cita-cita kemerdekaan bangsa Indonesia. 


\section{Simpulan}

Akun@karyaadalahdoa mampu tetap konsisten dalam pembuatan karya karya kreatifnya. Berdasarkan penelitian yang didapatkan dari hasil wawancara, @karyaadalahdoa ini bisa tetap konsisten karena Jokowi sedari awal konsisten. Begitupula terhadap karya yang dibuat. Dengan sikap konsisten, @ karyaadalahdoa ini yang membuat mereka semakin dikenal hingga sekarang. Sedangkan dari segi pembacanya juga tetap konsisten dalam menentukan pemilihannya ditambah dengan pemikiran yang lebih positif dalam menangkap pesan-pesan politiknya.

Akun@karyaadalahdoa memilliki tujuan dalam berkampanye politik ini yaitu mengedukasi masyarakat bahwa politik itu tidak selalu negatif. Dibuktikan dari akun @karyaadalahdoa, setiap karya yang mereka bagikan banyak mendapat respon masyarakat yang kagum dengan karya mereka. Dengan penyampaiannya yang singkat tetapi sangat jelas apa maksud dari pesan yang ingin disampaikannya cocok untuk anak-anak muda yang kurang memahami politik itu sendiri. Akun @karyaadalahdoa juga bekerja sama dengan berbagai relawan lainnya. Pesan yang disampaikan oleh akun @karyaadalahdoa ini bersifat detail dan terfokus. Peneliti memiliki pendapat bahwa dengan penyampaian berita yang dilakukan oleh @ karyaadalahdoa ini yang membuat masyarakat mulai berpikir selalu bersikap positif terhadap politik. Pengikut @karyaadalahdoa juga menyampaikan bahwa mereka memahami apa berita yang disampaikan oleh @karyaadalahdoa.

\section{Ucapan Terima Kasih}

Penulis mengucapkan terima kasih kepada Tuhan YME, dosen pembimbing, orang tua, teman-teman, dan juga narasumber yang sudah bersedia meluangkan waktunya serta seluruh pihak yang telah membantu penulis dalam menyelesaikan penelitian ini.

\section{Daftar Pustaka}

Budianto, Heri. (2011). Media dan Komunikasi Politik. Jakarta: Universitas Mercu Buana.

Cangara, Hafied. (2011). Komunikasi Politik : konsep, teori, dan strategi. Jakarta: PT Raja Grafindo Persada.

Gunawan, Imam. (2014). Metode Penelitian Kualitatif: Teori dan Praktik. Jakarta: Bumi Aksara.

Moleong, Lexy J. (2017). Metodologi Penelitian Kualitatif Edisi Revisi. Bandung: PT Remaja Rosdakarya.

Mukarom, Zaenal. (2016). Komunikasi Politik. Bandung: CV Pustaka Setia

Nasrullah, Rulli. (2017). Etnografi Virtual: Riset Komunikasi, Budaya, dan Sosioteknologi di Internet. Bandung: Simbiosa Rekatama Media.

Nasrullsh, Rulli. (2015). Media Sosial: Perspektif Komunikasi, Budaya, dan Sosioteknologi. Bandung: Simbiosa Rekatama Media.

Nazir, Moh. (2011). Metode Penelitian. Bogor: Penerbit Ghalia Indonesia.

Sarosa, Samiaji. (2012). Penelitian Kualitatif: Dasar-dasar. Jakarta: Permata Puri Media.

Simamarta, Salvatore. (2014). "Media Baru, Ruang Publik Baru, dan Transformasi Komunikasi Politik di Indonesia". Ejournal Universitas Atmajaya, Vol 3 No. 2. 
Susanto, Eko Harry. (2013). "Dinamika Komunikasi Politik Dalam Pemilihan Umum". Ejorunal Dosen Fakultas Ilmu Komunikasi Universitas Tarumanagara, Vol 1 No. 2. Hal 163-172

Watie, Errika Dwi Setya. (2011). "Komunikasi dan Media Sosial (Communications and Social Media)". Ejournal Dosen Ilmu Komunikasi Universitas Semarang, Vol 3 No. 2.

Yuningsih, Neny Agustin Irma. (2014). "Partisipasi Politik Remaja (Pemilih Pemula) Pada Pemilukada Mojokerto Tahun 2010 Di Desa Sumber Tanggul Kecamatan Mojosari Kabupaten Mojokerto". Ejournal PPKn FIS Universitas

Negeri Surabaya, Vol 1 No. 2. Hal 16-30. 